Please do not remove this page

RMIT

UNIVERSITY

\title{
Quench Sensitivity in a Dispersoid-Containing Al-Mg-Si Alloy
}

Strobel, Katharina; Easton, Mark; Lay, Matthew; Rometsch, Paul; Zhu, Suming; Sweet, Lisa; Parson, Nick https://researchrepository.rmit.edu.au/esploro/outputs/9921860738101341/filesAndLinks?institution=61RMIT_INST\&index=null

Strobel, K., Easton, M., Lay, M., Rometsch, P., Zhu, S., Sweet, L., Parson, N., \& Hill, A. (2019). Quench Sensitivity in a Dispersoid-Containing Al-Mg-Si Alloy. Metallurgical and Materials Transactions A: Physical Metallurgy and Materials Science, 50(4), 1957-1969. https://doi.org/10.1007/s11661-019-05130-2 Document Version: Accepted Manuscript

Published Version: https://doi.org/10.1007/s11661-019-05130-2

Repository homepage: https://researchrepository.rmit.edu.au

(c) The Minerals, Metals \& Materials Society and ASM International 2019

Downloaded On 2023/04/26 22:31:53 +1000 
2

\title{
Quench sensitivity in a dispersoid-containing Al-Mg-Si alloy
}

\author{
KATHARINA STROBEL, MARK A. EASTON, MATTHEW D. H. LAY, PAUL A. \\ ROMETSCH, SUMING ZHU, LISA SWEET, NICK C. PARSON, ANITA J. HILL
}

KATHARINA STROBEL, formerly with Department of Materials Science and Engineering, Monash University, Victoria 3800, Australia, is with AMAG Austria Metall, A-5282 BraunauRanshofen, Austria. MARK A. EASTON, formerly with Department of Materials Science and Engineering, Monash University, Victoria 3800, Australia, is with the School of Engineering, RMIT University, Carlton, Victoria 3053, Australia. Contact e-mail address: mark.easton@rmit.edu.au. MATTHEW D. H. LAY, formerly with CSIRO Manufacturing, Clayton, Victoria 3169, Australia, is with FB Rice, 90 Collins Street, Melbourne, Victoria 3000, Australia. PAUL A. ROMETSCH, formerly with Department of Materials Science and Engineering, Monash University, Victoria 3800, Australia, is with Rio Tinto Aluminium, Arvida Research and Development Center, Jonquière, Québec, G7S 4K8, Canada. SUMING ZHU, is with Department of Materials Science and Engineering, Monash University, Victoria 3800, Australia, and also with the School of Engineering, RMIT University, Carlton, Victoria 3053, Australia. LISA SWEET, was with Department of Materials Science and Engineering, Monash University, Victoria 3800, Australia. NICK C. PARSON is with Rio Tinto Aluminium, Arvida Research and Development Center, Jonquière, Québec, G7S 4K8, Canada. ANITA J. HILL is with CSIRO Manufacturing, Clayton, Victoria 3169, Australia. 


\section{Abstract}

The quench sensitivity of a 6xxx series alloy with a high content of dispersoids was studied over a wide range of cooling rate and natural aging time. Positron annihilation lifetime spectroscopy (PALS), differential scanning calorimetry (DSC) and transmission electron microscopy (TEM) were used to characterize the clustering and precipitation reactions. The alloy showed significant quench sensitivity after short natural aging ( $2 \mathrm{~min}$ and $30 \mathrm{~min}$ ), but the quench sensitivity was lower after long natural aging $(24 \mathrm{~h})$. The quench sensitivity after the long natural aging can be accounted for by solute loss due to the formation of non-hardening $\beta$ ' precipitates on the dispersoids during cooling from solution treatment. For short natural aging, however, quenched-in vacancies and modifications to the precipitation sequence also have substantial contributions to the quench sensitivity. This work provides new insight into the quench sensitivity of $6 \mathrm{xxx}$ series alloys that contain a high dispersoid density.

Keywords: Al-Mg-Si alloy; Quench sensitivity; Natural aging; Dispersoids; Precipitation 


\section{Introduction}

Aluminium alloys find broad use in many applications including the construction, aerospace and most recently automotive industries. 6xxx series alloys in particular have an excellent combination of strength to weight ratio, corrosion resistance and formability particularly through extrusion, rolling and other thermo-mechanical processing operations. One of the processing related issues that can affect the properties of these alloys is known as quench sensitivity. Quench sensitivity describes the effect that cooling rate, after homogenization or solution treatment of an alloy, has on the loss of properties, particularly strength. While 7xxx series $\mathrm{Al}$ alloys are known to be highly quench sensitive ${ }^{1}, \mathrm{Al}-\mathrm{Mg}-\mathrm{Si}$ based 6xxx series alloys, particularly those containing transition metals, can also show some degree of quench sensitivity 2, 3. The factors influencing quench sensitivity include dispersoid density, vacancy concentration and the kinetics of precipitation.

Dispersoids are introduced into higher strength 6xxx series alloys to control recrystallization and to improve fracture toughness. Dispersoids normally form during the heating stage of homogenization treatment in alloys containing Si, Fe and other transition metals, e.g. Mn and $\mathrm{Cr}{ }^{4-9}$. It has been shown that dispersoids play an important role in the quench sensitivity of 6xxx series alloys as non-hardening $\mathrm{Mg}-\mathrm{Si}$ phases tend to precipitate on them during cooling $3,10,11$. Since the formation of dispersoids is relatively complex 5, 12-15, careful temperature control is required in order to obtain a homogeneous distribution 4, 7, 12, 13. The composition, crystal structure and number density of dispersoids strongly depend on the alloy composition. In most $6 \mathrm{xxx}$ series alloys, the dispersoids are typically $\mathrm{Al}_{15} \mathrm{Mn}_{3} \mathrm{Si}_{2}$-phase with a simple cubic structure ${ }^{16,17}$. If the $\mathrm{Fe}$ content exceeds a certain limit $\left(\mathrm{Mn} / \mathrm{Fe}<1.6^{16}\right)$, a bodycentered cubic $\alpha-\mathrm{Al}_{12} \mathrm{Fe}_{3} \mathrm{Si}$-phase tends to form instead ${ }^{16}$. Both dispersoid phases, however, have the same lattice parameter $(a=12.6 \AA)$ so that they have the same lattice mismatch with the $\mathrm{Al}$ matrix. As the dispersoid/matrix interface is very similar in common $6 \mathrm{xxx}$ series alloys, it is the number density of dispersoids that determines the quench sensitivity ${ }^{11}$, which in turn depends on the homogenization time and temperature as well as the Mn and Cr contents ${ }^{18-21}$.

Recently, the current authors reported substantial quench sensitivity in a lean AA6060 alloy with few dispersoids particularly at short natural aging times $(<30 \text { minutes })^{22}$, indicating that the presence of "quenched-in vacancies" (as the result of rapid cooling) or "excess vacancies" (exceeding the equilibrium vacancy concentration) is also an influencing factor for quench 
sensitivity. Earlier studies on quench sensitivity and the effect of natural aging had already considered the effect of quenched-in vacancies on quench sensitivity 17, 23, 24 . However, it has only been since the year 2000 that further detailed investigations on the role of quenched-in vacancies in precipitation have been undertaken ${ }^{25-30}$.

The dependence of vacancy concentration on temperature and cooling rate has been studied ${ }^{25}$, 27,31 as well as the effect that vacancies have on the decomposition of the solid solution in $\mathrm{Al}$ alloys and consequently the age hardening response ${ }^{32-34}$. Based on a model derived by Fischer et al. ${ }^{31}$, which describes annihilation of excess vacancies on different types of sinks, Lang et al. ${ }^{27}$ and Falahati et al. ${ }^{25}$ determined the effect of cooling rate on excess vacancy concentration in an experimental alloy containing a very high $\mathrm{Si}$ content ${ }^{27}$ and the commercial $\mathrm{Al}-\mathrm{Mg}-\mathrm{Si}$ alloy AA $6016^{25}$, respectively. From their calculations, the vacancy site fraction after quenching from solution treatment at $823 \mathrm{~K}\left(550^{\circ} \mathrm{C}\right)$ varies between $5 \times 10^{-5}$ per atom for a very fast cooling rate of $10000 \mathrm{~K} / \mathrm{s}$ and $2 \times 10^{-9}$ per atom for a very slow cooling rate of $0.1 \mathrm{~K} / \mathrm{s}^{25}$. The equilibrium vacancy concentration of $\mathrm{Al}$ alloys at $298 \mathrm{~K}\left(25^{\circ} \mathrm{C}\right)$ is normally in the order of magnitude of $10^{-11}-10^{-12}$ per atom ${ }^{27,35}$. Hence, mobile, non-equilibrium vacancies can increase the diffusivity for self-diffusion of substitutional atoms by several orders of magnitude ${ }^{36,37}$.

The increased diffusivity of solute atoms due to the high number of mobile, non-equilibrium vacancies leads to an increased rate of precipitate formation during natural aging and possibly during subsequent artificial aging if the natural aging has been short 27, 38, 39. Vacancy annihilation and vacancy trapping can result in a reduction in the concentration of mobile vacancies to the equilibrium vacancy concentration over the course of about $100 \mathrm{~h}$ at room temperature irrespective of the cooling rate $25,27,34,40$. Likewise, annihilation of vacancies can reduce the natural aging response ${ }^{41}$.

It is also possible that the vacancy concentration may affect the clustering and precipitation sequence $^{42-44}$. Al-Mg-Si-alloys gain their strength mainly from Mg-Si-containing clusters and precipitates that form at room and elevated temperature. The precipitation sequence for alloys with a $\mathrm{Mg} / \mathrm{Si}$ ratio close to 2 (at.\%) is widely accepted to be:

$$
\text { SSSS } \rightarrow \text { clusters/co-clusters } \rightarrow \text { GP-zones } \rightarrow \beta^{\prime \prime} \rightarrow \beta^{\prime} \rightarrow \beta-\mathrm{Mg}_{2} \mathrm{Si}
$$


SSSS refers to supersaturated solid solution. Clusters can be defined as solute-rich groupings of atoms with undefined shape, chemistry and crystal structure ${ }^{45}$. They are part of the solid solution and may be present in states between the matrix and equilibrium state ${ }^{45}$. The major strengthening phase $\beta$ " has a base centered monoclinic structure ( $a=15.16 \AA, b=4.05 \AA$, $c=6.74 \AA, \beta=105.3^{\circ}$ ), with a stoichiometry close to $\mathrm{Mg}_{5} \mathrm{Si}_{6}{ }^{46,47} . \quad \beta$ ' is a hexagonal phase $(a=7.15 \AA, c=12.15 \AA)^{48-50}$, with a composition close to $\mathrm{Mg}_{9} \mathrm{Si}_{5}{ }^{50}$. $\quad \beta-\mathrm{Mg}_{2} \mathrm{Si}$ has a facecentered cubic structure $(a=6.40 \AA)^{49}$.

As the $\mathrm{Mg} / \mathrm{Si}$-ratio in the major strengthening phase, $\beta$ ", has been found to be close to $5 / 6$ at.\% 46, 47, 51, 52, Al-Mg-Si alloys with higher relative Si contents have been designed to improve hardness and strength, although this can complicate the precipitation sequence particularly towards the end including, B', $\mathrm{U}_{1}, \mathrm{U}_{2}$, Type A and Type B precipitates between the formation of $\beta$ ' and $\beta-\mathrm{Mg}_{2} \mathrm{Si}^{51-53}$. Since there are still some doubts over the exact composition of $\beta$ ", which has been recently been shown to contain $\mathrm{Al}^{54}$, and $\beta$, these phases will be referred to without a specified stoichiometry in this paper.

This paper investigates the influencing factors for quench sensitivity in a dispersoid-containing medium strength Al-Mg-Si alloy, which is a continuation of the authors' previous studies on the dependence of quench sensitivity on the number density of dispersoids ${ }^{11}$ and the effect of natural aging on quench sensitivity ${ }^{22}$ of Al-Mg-Si alloys. The microstructure and strength properties as a result of different cooling rates are investigated on three levels: firstly the precipitation of non-hardening phases is investigated by transmission electron microscopy (TEM) and differential scanning calorimetry (DSC); secondly, the evolution of mobile, nonequilibrium vacancies during natural and artificial aging is investigated by means of positron annihilation lifetime spectroscopy (PALS) and hardness measurements; and thirdly, the effect of cooling rate on the artificial aging response and the precipitating phases is investigated by TEM and DSC.

\section{Experimental Methods}

A model alloy with a composition of Al-0.67Si- $0.84 \mathrm{Mg}-0.35 \mathrm{Mn}-0.25 \mathrm{Fe}(\mathrm{wt} \%)$, as determined by Inductively Coupled Plasma - Atomic Emission Spectroscopy, was produced. Ingots were cast from commercially pure elements ( $\mathrm{Al}, \mathrm{Mg}$ and $\mathrm{Si}$ ) or master alloys ( $\mathrm{Mn}$ and $\mathrm{Fe}$ ) with the addition of $0.005 \mathrm{wt} . \%$ Ti from an Al-5Ti-1B master alloy into a pre-heated permanent steel 
mould. The melt temperature was $973 \mathrm{~K}\left(700^{\circ} \mathrm{C}\right)$ and the mould temperature approximately $623 \mathrm{~K}\left(350^{\circ} \mathrm{C}\right)$. In order to transform any unwanted primary $\beta$-AlFeSi intermetallic phase, dissolve primary $\beta-\mathrm{Mg}_{2} \mathrm{Si}$ and produce a homogeneous distribution of dispersoids, the ingots were heated at $200 \mathrm{~K} / \mathrm{h}$ to a homogenization temperature of $843 \mathrm{~K}\left(570^{\circ} \mathrm{C}\right)$ and then held for $2 \mathrm{~h}$ in a muffle furnace.

Details of the experimental procedure can be found elsewhere ${ }^{22}$, but a summary is provided here. After solution treatment for $1 \mathrm{~h}$ at $823 \mathrm{~K}\left(550^{\circ} \mathrm{C}\right)$, three cooling rates were investigated: water quenching (WQ) into room temperature water giving a cooling rate of $\sim 18,000 \pm 500$ $\mathrm{K} / \mathrm{min}$; oil quenching (OQ) into room temperature silicone oil giving a cooling rate of $\sim 2000 \pm$ $150 \mathrm{~K} / \mathrm{min}$; and air cooling (AC) on an alumina bed in still air at room temperature giving a cooling rate of $\sim 50 \pm 5 \mathrm{~K} / \mathrm{min}$. The cooling rates were determined by the linear approximation between $823 \mathrm{~K}\left(550^{\circ} \mathrm{C}\right)$ and $523 \mathrm{~K}\left(250^{\circ} \mathrm{C}\right)$ over time. Artificial aging was conducted in a silicone oil bath at $448 \mathrm{~K}\left(175^{\circ} \mathrm{C}\right)$ after natural aging (NA) for $2 \mathrm{~min}, 30 \mathrm{~min}$ and $24 \mathrm{~h}$. Vickers hardness was measured using a load of $0.3 \mathrm{~kg}$ for the naturally aged samples and $0.5 \mathrm{~kg}$ for the artificially aged samples.

DSC was conducted on a PerkinElmer DSC 7 to characterize precipitation reactions ${ }^{55}$ during cooling from solution treatment and during heating after $30 \mathrm{~min}$ or $24 \mathrm{~h} \mathrm{NA}$. The samples were given a simulated solution treatment cycle consisting of heating to $823 \mathrm{~K}\left(550^{\circ} \mathrm{C}\right)$, and holding for $1 \mathrm{~h}$, and were cooled at various rates from $5 \mathrm{~K} / \mathrm{min}$ to $150 \mathrm{~K} / \mathrm{min}$, limited by the sensitivity and the cooling capabilities of the apparatus.

A JEOL JSM-7001F field emission scanning electron microscope (FEG-SEM) was used to determine the distribution of secondary dispersoids after homogenization. Samples were prepared using standard metallographic techniques and finished with a colloidal silica suspension. The density of dispersoids was determined from at least ten SEM back scattered electron images per sample acquired at random locations. Image analysis was carried out using Adobe Photoshop Extended CS4 Win EULA software. A PHILIPS CM20 TEM, equipped with an Oxford INCA energy dispersive X-ray (EDX) spectrometer was used to characterize the size and crystal structure of non-hardening precipitates and compare the size and number density of the strengthening precipitates. The TEM foils were prepared by ion milling using a Gatan 691 Precision Ion Polishing System (PIPS). The web-based software package WebEMAPS ${ }^{56}$ was used to analyze the acquired selected area diffraction (SAD) patterns. 
PALS was used for the investigation of vacancy concentration and clustering phenomena $44,57-$ ${ }^{60}$. The PALS samples $\left(13 \times 13 \times 1 \mathrm{~mm}^{3}\right)$ were solution treated in a ceramic crucible in a vertical tube furnace under $50 \mathrm{l} / \mathrm{h} \mathrm{Ar}$ flow at $823 \mathrm{~K}\left(550^{\circ} \mathrm{C}\right)$ for $1 \mathrm{~h}$ and quenched either into water or silicone oil or cooled in still air on an alumina bed, which produced similar cooling rates to those experienced by the samples used for hardness measurement.

\section{III.Results}

\section{A. Age hardening response}

The age hardening response during natural aging (Figure 1) appears to be dependent on the cooling rate after solution treatment. In the WQ and OQ samples, the hardness increases faster and reaches higher values than in the AC sample. It should be noted that even after $10^{5} \mathrm{~min}(70$ days) natural aging, the hardness has not reached its peak.

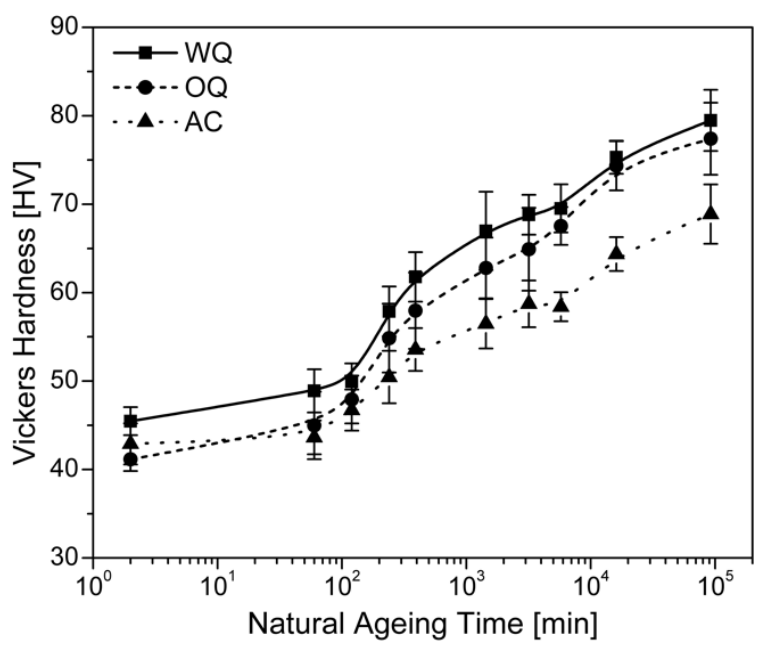

Figure 1. Age hardening response of the WQ, OQ and AC samples during natural aging.

Figure 2 shows the artificial aging response at $448 \mathrm{~K}\left(175^{\circ} \mathrm{C}\right)$ after $2 \mathrm{~min}, 30 \mathrm{~min}$ and $24 \mathrm{~h}$ natural aging. The hardness upon artificial aging is generally greatest for the WQ sample and lowest for the AC sample. The respective WQ sample reaches its peak hardness earlier than the OQ and AC samples. The quench sensitivity of the alloys can be seen by the difference in hardness between the WQ and AC samples. This difference will be used as a measure of quench sensitivity hereafter in the paper. 

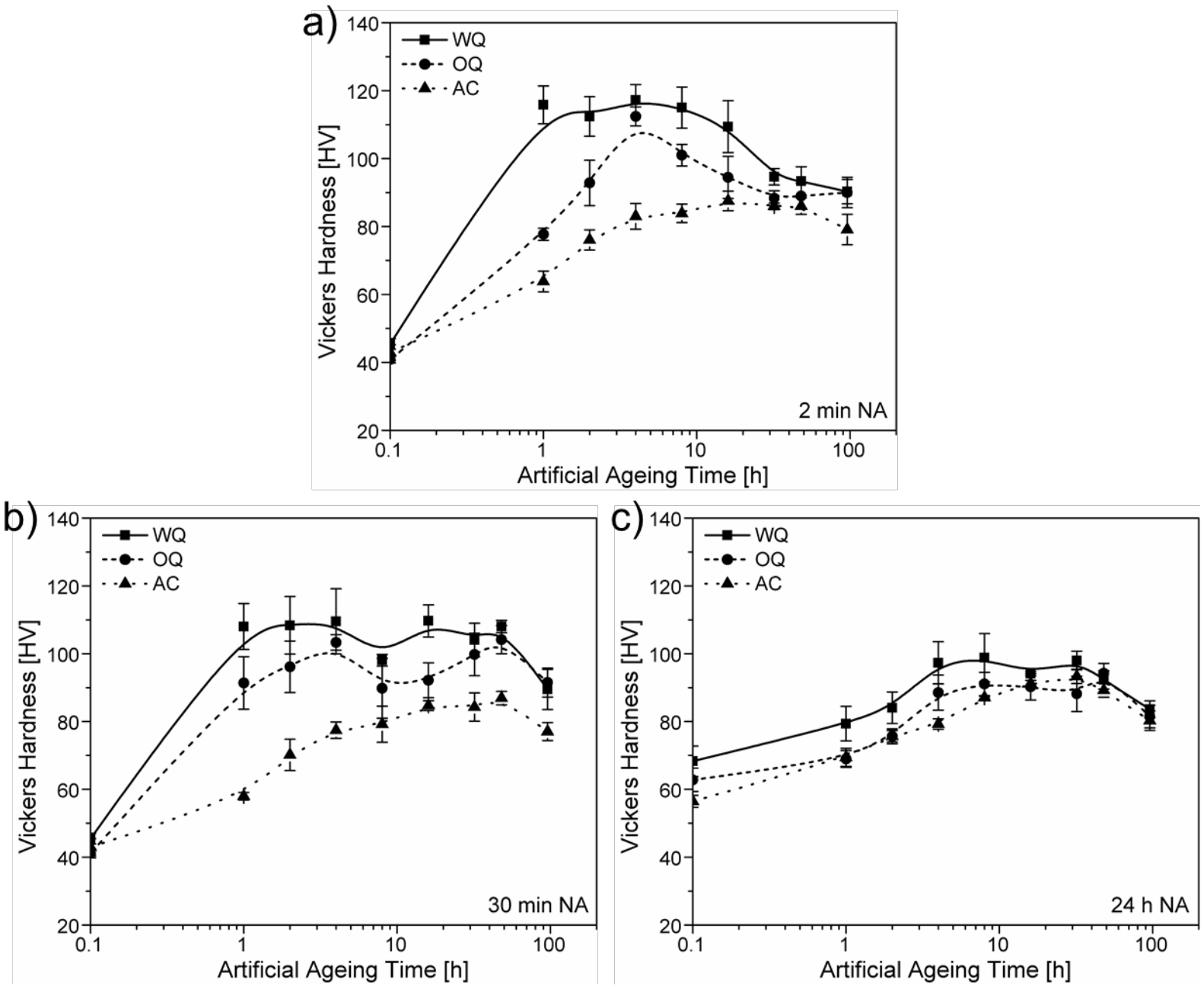

183

Figure 2 Artificial age hardening response at $448 \mathrm{~K}\left(175^{\circ} \mathrm{C}\right)$ for the WQ, OQ and AC samples after (a) $2 \mathrm{~min}$, (b) $30 \mathrm{~min}$ and (c) $24 \mathrm{~h}$ natural aging.

After 2 min natural aging, the hardness values for the differently quenched samples are similar. Upon artificial aging, the WQ sample reaches the peak hardness after $1 \mathrm{~h}$, the time when the first measurement was taken. The peak hardness for the 2 min natural aging sample is $117 \pm 5 \mathrm{Hv}$ (Table 1), which is the maximum hardness achieved in this study. The AC sample reaches its maximum hardness of $88 \pm 3 \mathrm{Hv}$ after $16 \mathrm{~h}$ (Table 1). It is clear that the increment in hardness by artificial aging is largest in the WQ sample and smallest in the AC sample. 
Table 1 Summary of the hardness at different natural aging times and the peak hardness and the time to peak hardness (in bracket) upon artificial aging at $175^{\circ} \mathrm{C}$.

\begin{tabular}{ccccccc}
\hline \multirow{2}{*}{$\begin{array}{c}\text { Natural Aging } \\
\text { Time }\end{array}$} & \multicolumn{3}{c}{$\begin{array}{c}\text { Hardness [Hv] } \\
\text { (Natural Aging) }\end{array}$} & \multicolumn{4}{c}{$\begin{array}{c}\text { Peak Hardness [Hv] } \\
\text { (Artificial Aging) }\end{array}$} \\
\cline { 2 - 7 } & WQ & OQ & AC & WQ & OQ & AC \\
\hline 2 min & $45 \pm 2$ & $41 \pm 1$ & $43 \pm 2$ & $117 \pm 5(1 \mathrm{~h})$ & $112 \pm 3(4 \mathrm{~h})$ & $88 \pm 3(16 \mathrm{~h})$ \\
$30 \mathrm{~min}$ & $50 \pm 2$ & $48 \pm 3$ & $47 \pm 2$ & $110 \pm 6(4 \mathrm{~h})$ & $103 \pm 3(4 \mathrm{~h})$ & $87 \pm 2(48 \mathrm{~h})$ \\
$24 \mathrm{~h}$ & $67 \pm 4$ & $63 \pm 3$ & $57 \pm 3$ & $100 \pm 6(8 \mathrm{~h})$ & $91 \pm 3(8 \mathrm{~h})$ & $93 \pm 2(32 \mathrm{~h})$ \\
\hline
\end{tabular}

Compared to the $2 \mathrm{~min}$ natural aging, there is an apparent increase in hardness after $24 \mathrm{~h}$ natural aging, with the hardness being highest for the WQ sample and lowest for the AC sample (compare Figure 1 and Figure 2). However, the respective peak hardness values after artificial aging are much lower than those with 2 min natural aging for the WQ and OQ samples (Table 1). This negative effect of natural aging has been identified previously in highly alloyed 6xxx series alloys ${ }^{61-63}$. It is to be noted that the AC sample does not exhibit such a negative effect of natural aging. Although the WQ sample reaches maximum hardness significantly earlier than the $\mathrm{AC}$ sample ( $8 \mathrm{~h}$ versus $32 \mathrm{~h}$ ), it is actually the latter that shows the largest increment in hardness for the $24 \mathrm{~h}$ natural aging condition (Table 1). As a result, the difference in the peak hardness between the different cooling conditions is much less pronounced for the $24 \mathrm{~h}$ natural aging as compared to the 2 min natural aging.

\section{B. Thermal analysis}

\section{Precipitation during cooling after solution treatment}

Figure 3 shows the cooling rate dependence of the precipitation of two different phases during cooling after solution treatment where the non-hardening precipitates form on the dispersoids. At lower cooling rates a clear separation of the two peaks is evident. With increasing cooling rate the high temperature peak appears to shift to lower temperatures and is not discernible for cooling rates greater than $100 \mathrm{~K} / \mathrm{min}$. The overall formation enthalpy (Figure $3 \mathrm{~b}$ ) is the sum of the formation of the high temperature phase $\left(\beta-\mathrm{Mg}_{2} \mathrm{Si}\right)$ and the low temperature phase $(\beta$ '). It can be observed that over $90 \%$ of the solute loss is related to the lower temperature reaction and the higher temperature reaction is relatively constant over the cooling rate range. These results are similar to those obtained previously in the dispersoid-free alloy ${ }^{22}$. Thus, this paper will focus on the low temperature $\beta$ ' reaction as the major source of quench sensitivity. 
Comparable experiments in the literature for the commercial alloy AA6005A also show a slightly decreased or rather constant enthalpy of formation for the high temperature phases for cooling rates lower than $10 \mathrm{~K} / \mathrm{min}^{64}$.
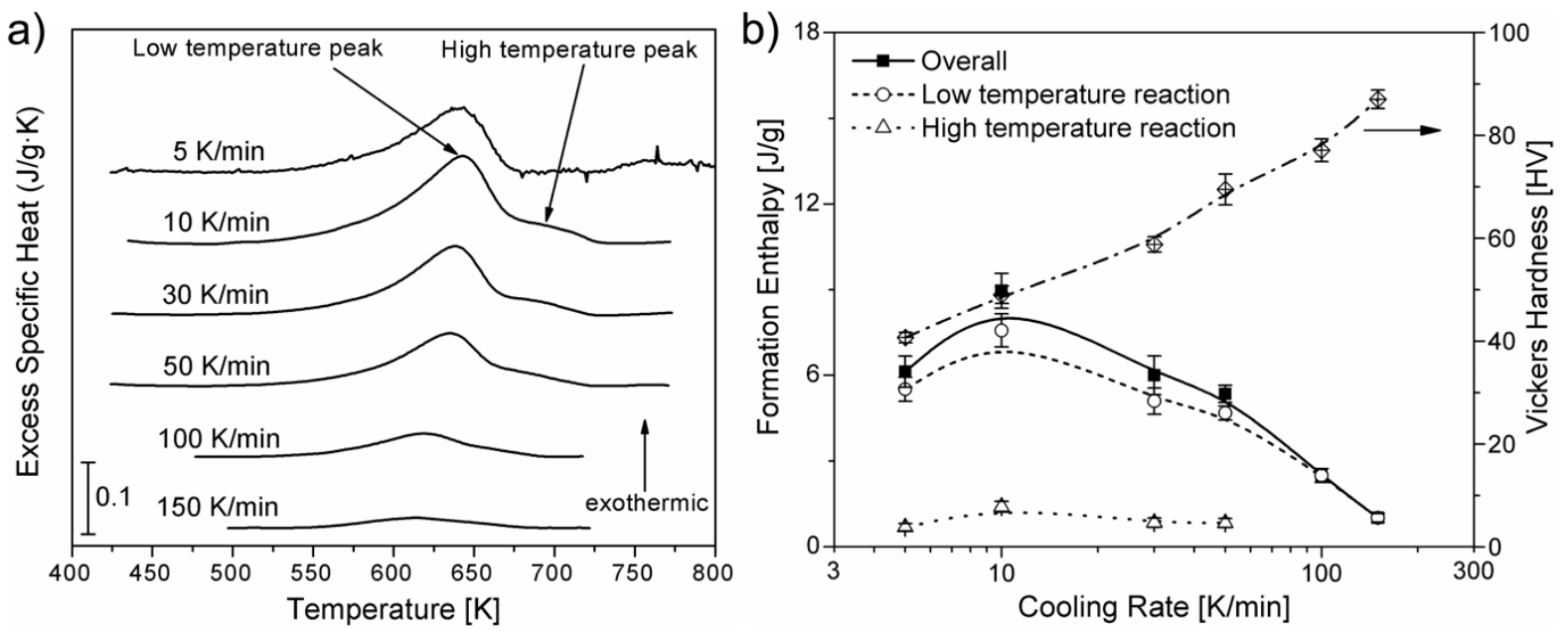

Figure 3 (a) DSC curves during cooling from $823 \mathrm{~K}\left(550^{\circ} \mathrm{C}\right)$ at different cooling rates showing the precipitation of $\beta-\mathrm{Mg}_{2} \mathrm{Si}$ (high temperature peak) and $\beta$ ' (low temperature peak) in the alloy. It should be noted that the baseline for the different cooling rates is offset for clarity. (b) Enthalpies of precipitation during cooling plotted against cooling rate. Also shown in (b) are hardness data measured on the samples cooled at different rates.

\section{Precipitation of strengthening phases upon artificial aging}

Figure 4 shows DSC scans at a heating rate of $20 \mathrm{~K} / \mathrm{min}$ for the WQ and AC samples after 30 min natural aging (Figure 4a) or $24 \mathrm{~h}$ natural aging (Figure $4 \mathrm{~b}$ ). While the WQ sample shows distinct peaks for clustering, precipitation and dissolution reactions, some peaks in the AC sample are either not obvious or overlap. The WQ sample after both natural aging times shows four exothermic peaks that are attributed to A: cluster formation, $\mathrm{C}$ : formation of $\beta$ " precipitates, $\mathrm{D}$ : formation of $\beta$ ' precipitates and $\mathrm{E}$ : formation of $\beta-\mathrm{Mg}_{2} \mathrm{Si}$ precipitates. The endothermic peak (B) is attributed to dissolution of clusters. The peaks for cluster formation (A) and dissolution (B) are observed at approximately $363 \mathrm{~K}\left(90^{\circ} \mathrm{C}\right)$ and approximately $503 \mathrm{~K}\left(230^{\circ} \mathrm{C}\right)$ respectively for the WQ sample, but they are not detected in the AC sample. This might be due to the clustering being suppressed as a result of a lack of mobile vacancies and reduced solute supersaturation. In the $\mathrm{AC}$ sample the peaks for $\beta$ " and $\beta$ ' precipitation $(\mathrm{C}$ and $\mathrm{D})$ overlap greatly and de-convolution is therefore difficult. Peak E occurs at the same temperature for both $\mathrm{AC}$ and WQ samples and is approximately the same size. 

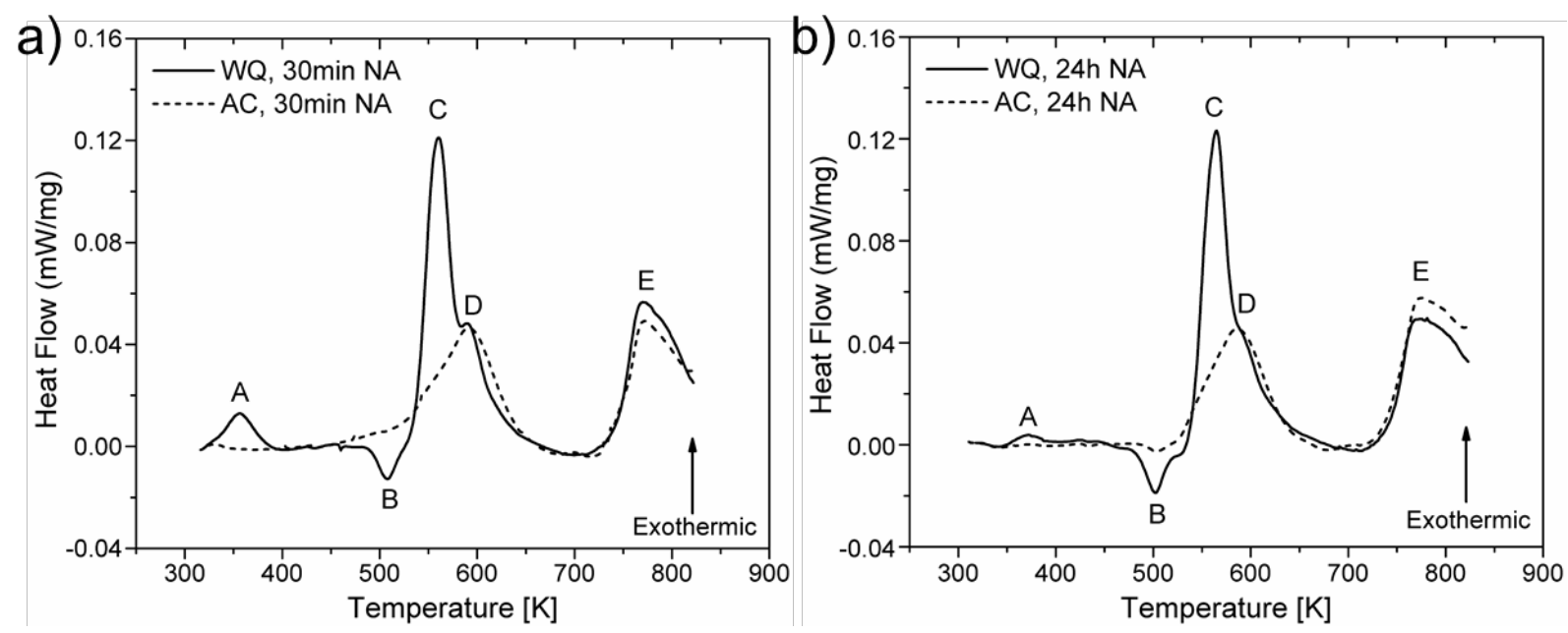

Figure 4 DSC curves at a heating rate of $20 \mathrm{~K} / \mathrm{min}$ for the WQ and AC samples naturally aged for (a) $30 \mathrm{~min}$ and (b) $24 \mathrm{~h}$. The letters A to E indicate exo- and endothermic peaks.

247 The effect of natural aging is noticeable when comparing the DSC scans of the two WQ samples (Figure 4). After 30 min natural aging the peak for clustering (A) is larger than after $24 \mathrm{~h}$ natural aging, showing that clustering has already occurred during $24 \mathrm{~h}$ natural aging. Significant cluster dissolution peaks (B) are observed in the two WQ samples after both $30 \mathrm{~min}$ and $24 \mathrm{~h}$ natural aging.

The formation of $\beta$ " and $\beta$ ' precipitates appears to be significantly different in the WQ and AC samples (Figure 4). The WQ sample shows a large peak for $\beta$ "-formation and a significantly smaller peak for $\beta$ '-formation (Table 2, Figure 5). For the AC sample the combined $\beta$ " and $\beta$ ' peak is at a similar temperature as the $\beta$ '-peak in the WQ sample but the size of the $\beta$ " precipitation peak is clearly much smaller. As a result, $\Delta \mathrm{H}_{\beta}{ } / \Delta \mathrm{H}_{\beta}$, is greater than one for the WQ sample and less than one for the AC sample. This suggests that $\beta$ ' forms preferentially to $\beta$ "-precipitation in the AC sample. Since $\beta$ ' is less effective in strengthening compared to $\beta$ " 46 , 50,51 , the quench sensitivity is clearly also affected. 


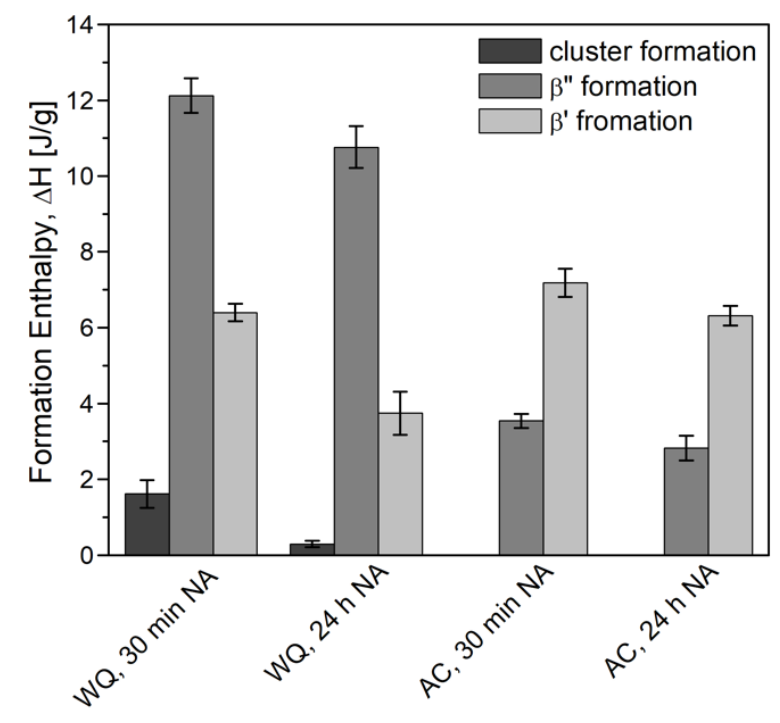

Figure 5 Enthalpies for formation of cluster, $\beta$ " and $\beta$ ' during heating at $20 \mathrm{~K} / \mathrm{min}$ for the WQ and $\mathrm{AC}$ samples after natural aging for $30 \mathrm{~min}$ and $24 \mathrm{~h}$ showing the relative amounts of phases that are formed.

Table 2 The peak temperature and formation enthalpy for $\beta$ " and $\beta$ ' formation in the WQ and AC samples after $30 \mathrm{~min}$ and $24 \mathrm{~h}$ natural aging during heating at $20 \mathrm{~K} / \mathrm{min}$.

\begin{tabular}{ccccccc}
\hline & \multicolumn{2}{c}{ Clustering (A) } & \multicolumn{2}{c}{$\beta$ ' Formation $(\mathrm{C})$} & \multicolumn{2}{c}{$\beta$ ' Formation (D) } \\
\cline { 2 - 7 } Sample & $\begin{array}{c}\text { Peak } \\
\text { Temperature } \\
{[\mathrm{K}]}\end{array}$ & $\begin{array}{c}\text { Enthalpy } \\
{[\mathrm{J} / \mathrm{g}]}\end{array}$ & $\begin{array}{c}\text { Peak } \\
\text { Temperature } \\
{[\mathrm{K}]}\end{array}$ & $\begin{array}{c}\text { Enthalpy } \\
{[\mathrm{J} / \mathrm{g}]}\end{array}$ & $\begin{array}{c}\text { Peak } \\
\text { Temperature } \\
{[\mathrm{K}]}\end{array}$ & $\begin{array}{c}\text { Enthalpy } \\
{[\mathrm{J} / \mathrm{g}]}\end{array}$ \\
\hline WQ + 30 min NA & $356 \pm 2$ & $1.6 \pm 0.4$ & $557 \pm 2$ & $12 \pm 0.5$ & $595 \pm 1$ & $6.4 \pm 0.2$ \\
WQ + 24 h NA & $369 \pm 2$ & $0.3 \pm 0.1$ & $562 \pm 2$ & $11 \pm 0.6$ & $603 \pm 1$ & $3.7 \pm 0.6$ \\
AC + 30 min NA & - & - & $545 \pm 4$ & $3.5 \pm 0.2$ & $600 \pm 2$ & $7.2 \pm 0.4$ \\
AC 24 h + NA & - & - & $559 \pm 1$ & $2.8 \pm 0.3$ & $598 \pm 1$ & $6.3 \pm 0.3$ \\
\hline
\end{tabular}

The activation energies $\left(E_{a}\right)$ for the formation of the different phases precipitating during natural aging were determined for the WQ and AC samples from linear heating studies using a Type B-1.95 Peak method ${ }^{65}$. The estimated activation energies are summarized in Table $\mathbf{3}$ and compared with the literature ${ }^{66}$. 
Table 3 Activation energy of phase transformation occurring during heating for WQ and AC samples after $30 \mathrm{~min}$ and $24 \mathrm{~h}$ natural aging.

Cluster Cluster $\quad \beta$ ”- $\quad \beta$ ” to $\beta$ '- $\quad \beta$-Formation

Sample Formation Dissolution Precipitation Transformation $\left(\mathrm{kJ} \mathrm{mol}^{-1}\right)$ $\left(\mathrm{kJ} \mathrm{mol}^{-1}\right) \quad\left(\mathrm{kJ} \mathrm{mol}^{-1}\right) \quad\left(\mathrm{kJ} \mathrm{mol}^{-1}\right) \quad\left(\mathrm{kJ} \mathrm{mol}^{-1}\right)$

\begin{tabular}{cccccc}
\hline $\mathrm{WQ}+30$ min NA & 47 & 128 & 92 & 100 & 231 \\
$\mathrm{WQ}+24 \mathrm{~h} \mathrm{NA}$ & 32 & 165 & 109 & 111 & 476 \\
$\mathrm{AC}+30 \mathrm{~min} \mathrm{NA}$ & - & - & 162 & 105 & 281 \\
$\mathrm{AC}+24 \mathrm{~h} \mathrm{NA}$ & - & - & 90 & 96 & 418 \\
\hline $\begin{array}{c}\mathrm{Al}-1.12 \\
\text { wt. } \% \mathrm{Mg}_{2} \mathrm{Si}-0.35\end{array}$ \\
$\begin{array}{c}\text { wt. } \% \mathrm{Si} \\
66\end{array}$
\end{tabular}

\section{Microstructure Characterization}

The SEM examinations (not shown) revealed the presence of coarse, Chinese-script-like $\alpha$ $\mathrm{Al}(\mathrm{Fe}, \mathrm{Mn}) \mathrm{Si}$ intermetallics at grain boundaries and a dense distribution of secondary $\alpha$ $\mathrm{Al}(\mathrm{Fe}, \mathrm{Mn}) \mathrm{Si}$ dispersoids with a density of $3 \times 10^{5} / \mathrm{mm}^{2}$ within the grains in the alloy after homogenization treatment (Figure 6).

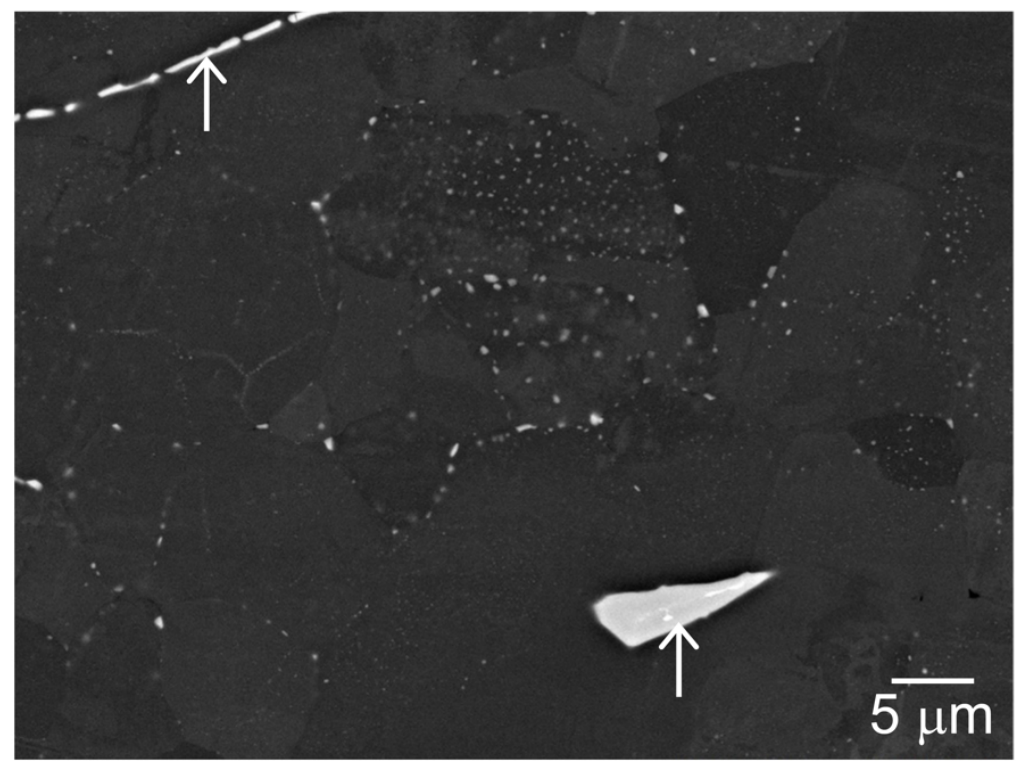

Figure 6. SEM backscattered electron image showing $\alpha-\mathrm{Al}(\mathrm{Fe}, \mathrm{Mn}) \mathrm{Si}$ intermetallics (arrowed) and dispersoids in the alloy after the homogenization treatment. 
In the AC sample, the microstructure is dominated by coarse, non-hardening precipitates that form during the low temperature reaction (Figure 7). They precipitate heterogeneously on secondary dispersoids. These non-hardening precipitates contain $\mathrm{Mg}, \mathrm{Si}$ and possibly $\mathrm{Al}$ and have an atomic $\mathrm{Mg}$ :Si-ratio close to $\mathrm{Mg}_{2} \mathrm{Si}$ (Figure 7c). The SAD patterns identified the nonhardening precipitates as $\beta$ ' (Figure 8 ). This phase has recently been denoted as $\mathrm{B}^{3}{ }^{3}$ but we will use the traditional nomenclature. Around these particles are precipitation free zones (PFZs), which are not observed in the WQ and OQ samples as have been observed previously ${ }^{11,22}$. The volume fraction of the PFZ in the AC sample was determined to be about $20 \pm 2 \%$. This is a considerable amount compared to lean Al-Mg-Si alloys where the PFZ is only about $1 \%$ of the matrix due to a very low density of dispersoids ${ }^{22}$.
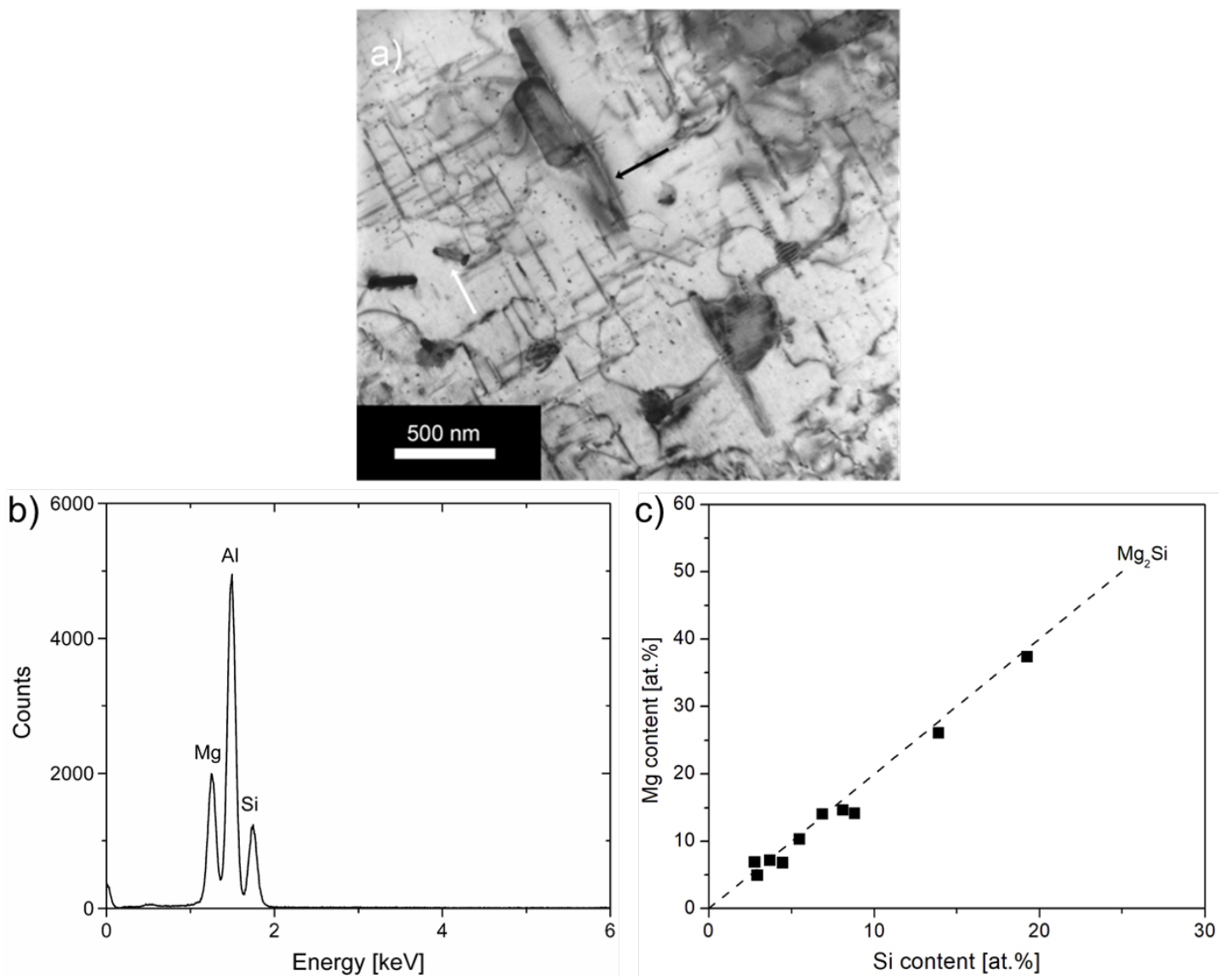

Figure 7 (a) TEM micrograph showing the non-hardening $\beta^{\prime}$ precipitates nucleated on the coarse dispersoids in the AC sample naturally aged for $24 \mathrm{~h}$ and then artificially aged for $8 \mathrm{~h}$ at $448 \mathrm{~K}\left(175^{\circ} \mathrm{C}\right)$, (b) typical EDX spectrum and (c) plot of the EDX measured Mg content versus Si content of the $\beta^{\prime}$ precipitates. The $\mathrm{Mg}$ :Si-ratio of ten $\beta^{\prime}$ precipitates found on dispersoids throughout the alloy which is observed to be close to that of $\mathrm{Mg}_{2} \mathrm{Si}$ phase. The arrows in (a) indicate the $\beta^{\prime}$ precipitates in two different orientations. 


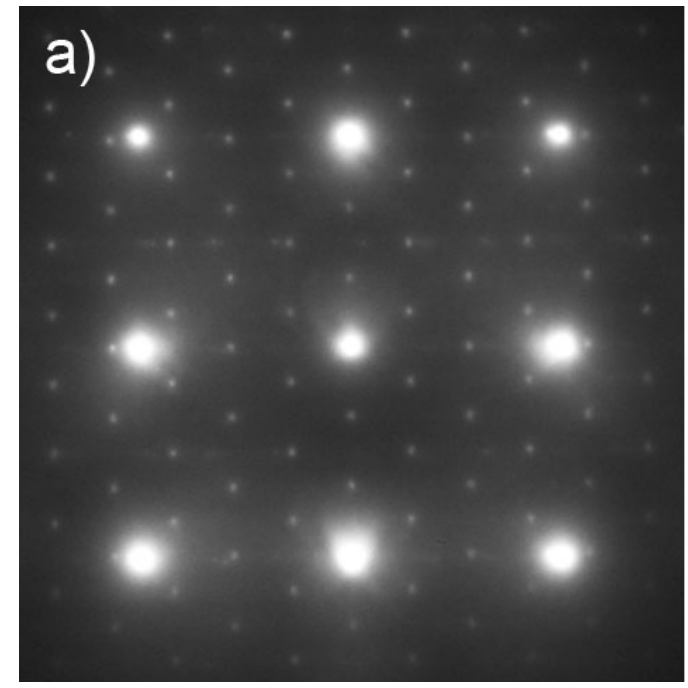

b)

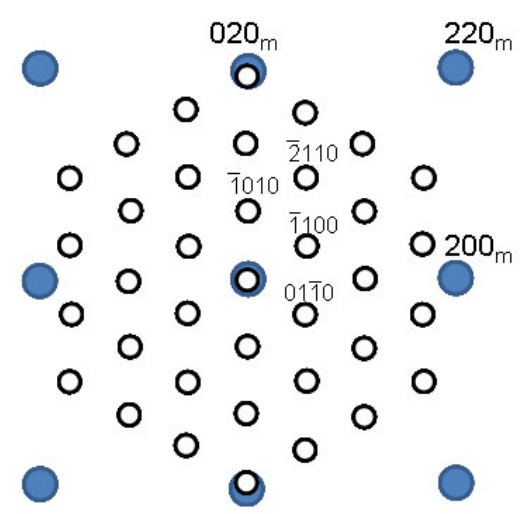

Figure 8 (a) Selected area diffraction pattern of a non-hardening precipitate and matrix from $[0001]_{\beta}, /[001]_{\mathrm{Al}}$ and (b) schematic illustration of a $\beta$ '-precipitate and Al-matrix. Open and closed circles indicated diffraction spots of the precipitate and matrix, respectively.

The microstructure of the samples with different quenching and aging conditions can be found in Figure 9 and Figure 10. After 30 min natural aging and $1 \mathrm{~h}$ artificial aging, the distribution of strengthening precipitates is very different depending on the cooling rate. While the WQ sample (Figure 9a) shows very small and almost equi-axed precipitates indicating $\beta$ " and some rod shaped $\beta$ ', fewer precipitates can be seen in the AC sample (Figure 9b). This is in good agreement with the hardness data (Figure 2b), where the WQ sample shows significantly higher values than the AC sample that has not experienced a major increase in strength after one hour of artificial aging.
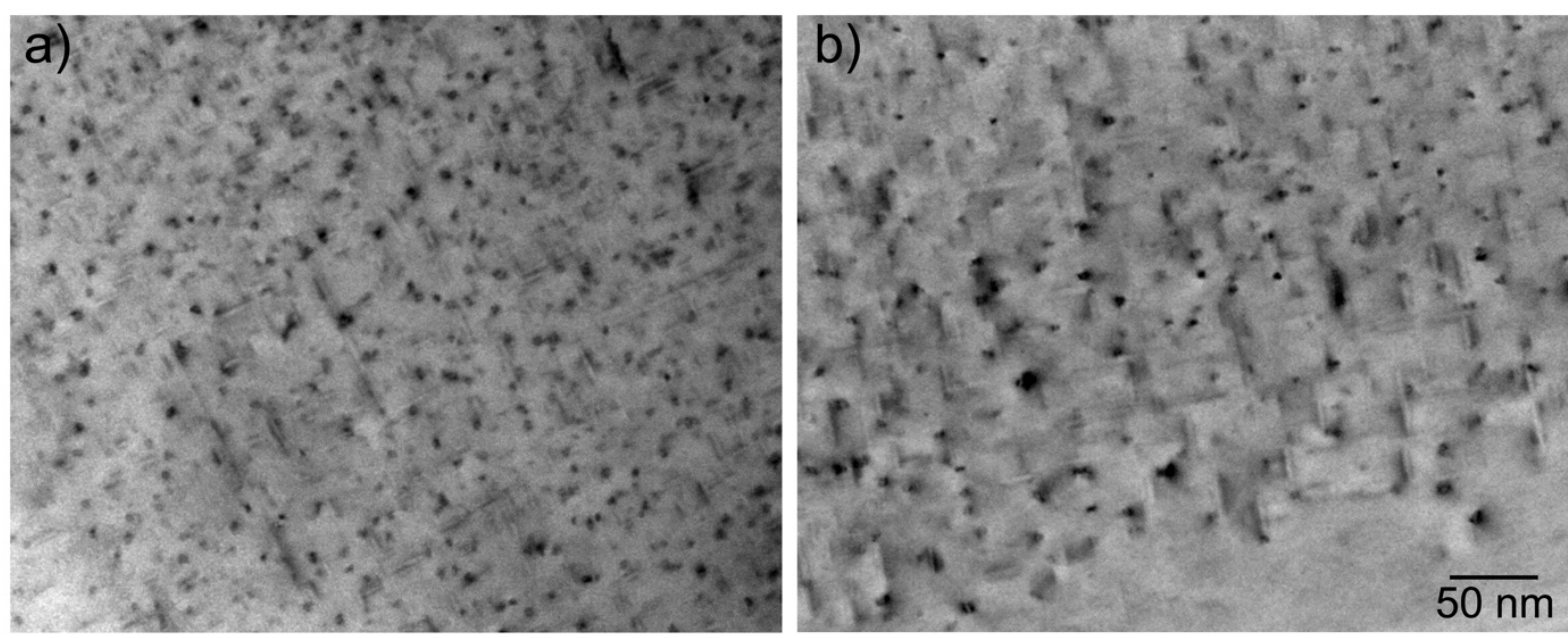
Figure 9 TEM micrographs along $<001>_{\mathrm{Al}}$ showing precipitates in the (a) WQ and (b) AC samples after $30 \mathrm{~min}$ natural aging and further $1 \mathrm{~h}$ artificial aging at $448 \mathrm{~K}\left(175^{\circ} \mathrm{C}\right)$. Both images are the same scale.
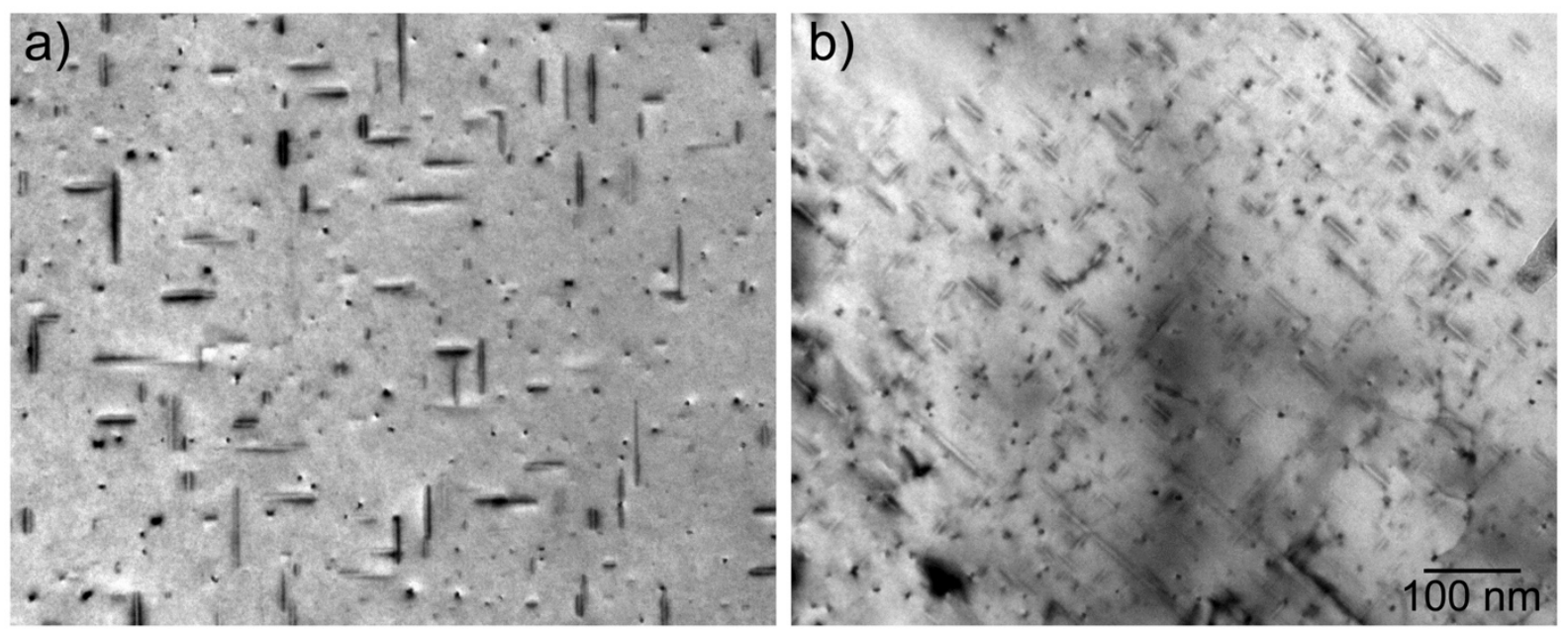

Figure 10 TEM micrographs along $<001>_{\mathrm{Al}}$ showing precipitates in the (a) WQ and (b) AC samples after $24 \mathrm{~h}$ natural aging and further $8 \mathrm{~h}$ artificial aging at $448 \mathrm{~K}\left(175^{\circ} \mathrm{C}\right)$. Both images are the same scale.

After $24 \mathrm{~h}$ natural aging and $8 \mathrm{~h}$ artificial aging, the size and number density of strengthening precipitates appears to be very similar in the WQ (Figure 10a) and AC samples (Figure 10b). This also correlates well with the hardness values, which are similar for this aging condition (Figure 2c). The strengthening precipitates appear to be $\beta$ ' due to the elongated rod morphology. They are significantly larger in size than after the short aging treatment.

\section{Characterization by Positron Annihilation Lifetime Spectroscopy (PALS)}

PALS was used to monitor the vacancy concentration and clustering reactions during natural aging, on solution treated samples that were cooled at the different rates. To assist with the interpretation of these results the following information from the literature is required. Wellannealed Al has a positron lifetime of approximately 162-168ps ${ }^{67-69}$. Quenched-in vacancies increase positron lifetime considerably and there is a decay in positron lifetime after quenching until the equilibrium vacancy contribution is reached ${ }^{22,44}$. Although the effect of clustering and precipitation on positron lifetime is complicated, clustering tends to increase positron lifetime towards approximately $220-230 \mathrm{ps}^{44,59,70}$. 
The evolution of the average positron lifetime during natural aging in the investigated alloy is presented in Figure 11. The initial positron lifetimes of the three samples are in similar order of magnitude to pure $\mathrm{Al}$ and AA6060 investigated in a previous study ${ }^{22}$, with the WQ sample exhibiting the highest lifetime at $\sim 220$ ps, followed by 215 ps for the OQ sample and 205 ps for the $\mathrm{AC}$ sample. In contrast to pure $\mathrm{Al}^{22}$, in which the positron lifetime decreases during natural aging as a result of the annihilation of excess vacancies, the positron lifetime of the three samples investigated shows an initial increase, followed by a decrease with natural aging. The WQ sample reaches a peak of 230 ps after 20 min natural aging and the OQ sample reaches a peak of $\sim 220$ ps after 30 min natural aging. After 100 min natural aging, both WQ and OQ samples reach a local minimum of 217 ps. At the same time, after a steady increase, the AC sample reaches the same average lifetime of 217 ps. Beyond this point, the positron lifetime appears to be independent of the cooling rate, increasing slightly to a local maximum of $219 \mathrm{ps}$ after 300 min natural aging before decreasing slowly.

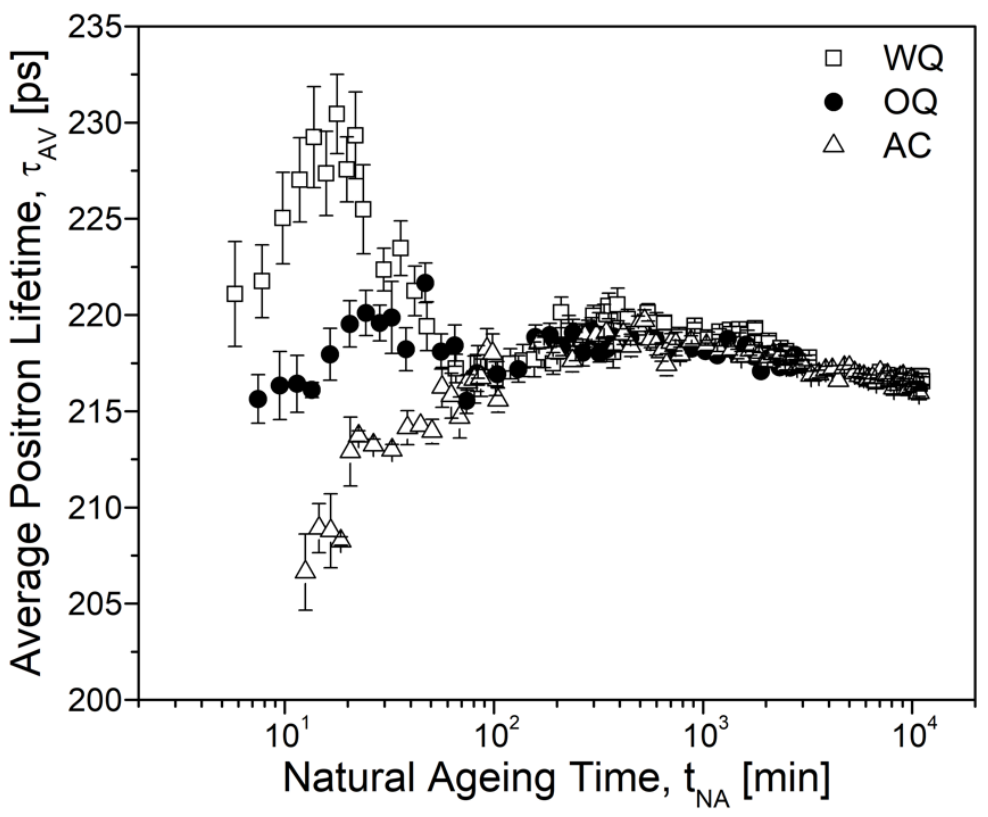

Figure 11 Evolution of the average positron lifetime, $\tau_{\mathrm{AV}}$, in the WQ, OQ and AC samples during natural aging.

\section{IV.Discussion}

For the dispersoid-containing alloy studied with a combined $\mathrm{Mg}$ and $\mathrm{Si}$ contents above $1.0 \mathrm{wt} \%$, that experiences significant nucleation of non-hardening precipitates on dispersoids during slow 
cooling, solute loss and non-equilibrium vacancies appear to be contributing factors to quench sensitivity. In addition to these two factors, a change in the precipitation sequence with cooling rate is also observed in this study (Figure 4). The discussion will therefore attempt to provide a plausible explanation for the observed quench sensitivity by taking into account these factors.

Before discussing the quench sensitivity data, it is important to understand the state of the samples after each natural aging time. The initial positron lifetime measurement was at approximately 5 minutes natural aging, which is close to the 2 min natural aging used in the aging tests. The initial positron lifetime (Figure 11) indicates differences in the concentration of quench-induced vacancies. This is, as expected, highest in the WQ sample, followed by the OQ and AC samples. The initial average positron lifetime of the WQ sample of $\sim 221$ ps is on the lower end of the range of those reported in literature, which vary between 224-245ps for similar alloys $22,44,59$.

At 30 minutes natural aging the positron lifetime in the WQ sample is decreasing after an initial increase, the OQ sample is beginning to decrease after a similar initial increase whilst the AC sample is increasing. The initial increase in average positron lifetime observed in both WQ and OQ samples is probably related to the early clustering reactions that occur during the early stages of natural aging ${ }^{71}$. A decrease in positron lifetime in the early stages of natural aging is probably related to the annihilation or trapping of vacancies ${ }^{22,44}$. This means that at 30 mins, there has been some clustering in both the WQ and OQ samples and they still have some supersaturation of vacancies. The AC sample shows some evidence of clustering only.

At 24 hours natural aging the positron lifetime is similar for each of the quench rates indicating that the vacancies are no longer supersaturated and the state of clustering/precipitation is also similar.

\section{A. Quantification of the contribution of solute loss to quench sensitivity}

Solute loss due to the precipitation of non-hardening $\beta^{\prime}-\mathrm{Mg}-\mathrm{Si}$ on dispersoids has been understood to be responsible for the reduced hardening response of $\mathrm{Al}-\mathrm{Mg}$-Si alloys that are cooled below the critical cooling rate ${ }^{19,64,72}$. This leads to the formation of PFZs during the artificial aging process (Figure 7). The hardness measured during artificial aging after prolonged $(24 \mathrm{~h})$ natural aging offers the closest approximation of hardness evolution independent of mobile vacancies, since non-equilibrium vacancies have either annihilated or 
been trapped in clusters. The hardness evolution after $24 \mathrm{~h}$ natural aging (Figure $2 \mathrm{c}$ ) shows that solute loss leads to a significant reduction in achievable hardness, especially at the artificial aging times of commercial interest $(<8 \mathrm{~h})$.

The effect of solute loss can be determined by assuming that the achievable hardness can be described by a simple composite model,

$$
H V=\alpha \cdot H V_{s s}+(1-\alpha) \cdot H V_{p p t}
$$

where $\alpha$ is the volume fraction of the PFZs which in this case is $20 \%$ in the AC sample (Section III.C), $\mathrm{HV}_{\mathrm{SS}}$ the hardness of the precipitate-free solid solution and $\mathrm{HV}_{\mathrm{ppt}}$ the hardness of precipitation-strengthened matrix.

The hardness of the solid solution $\left(\mathrm{HV}_{\mathrm{ss}}\right)$ is assumed to be similar to the hardness of the AC sample straight after quenching $(42.9 \mathrm{Hv})$ and $\mathrm{HV}_{\mathrm{ppt}}$ is the hardness of the corresponding WQ sample (where the PFZ is negligible) at the same age-hardening treatment as the AC sample being investigated. By using the corresponding WQ sample the strengthening contributions of primary intermetallics and secondary dispersoids are included in $\mathrm{HV}_{\mathrm{ppt}}$. Taking solute loss due to natural aging into account, the age hardening response of the AC samples with different natural aging times can be calculated using Eq. 1, and a comparison with the measured ones is shown in Figure 12. 

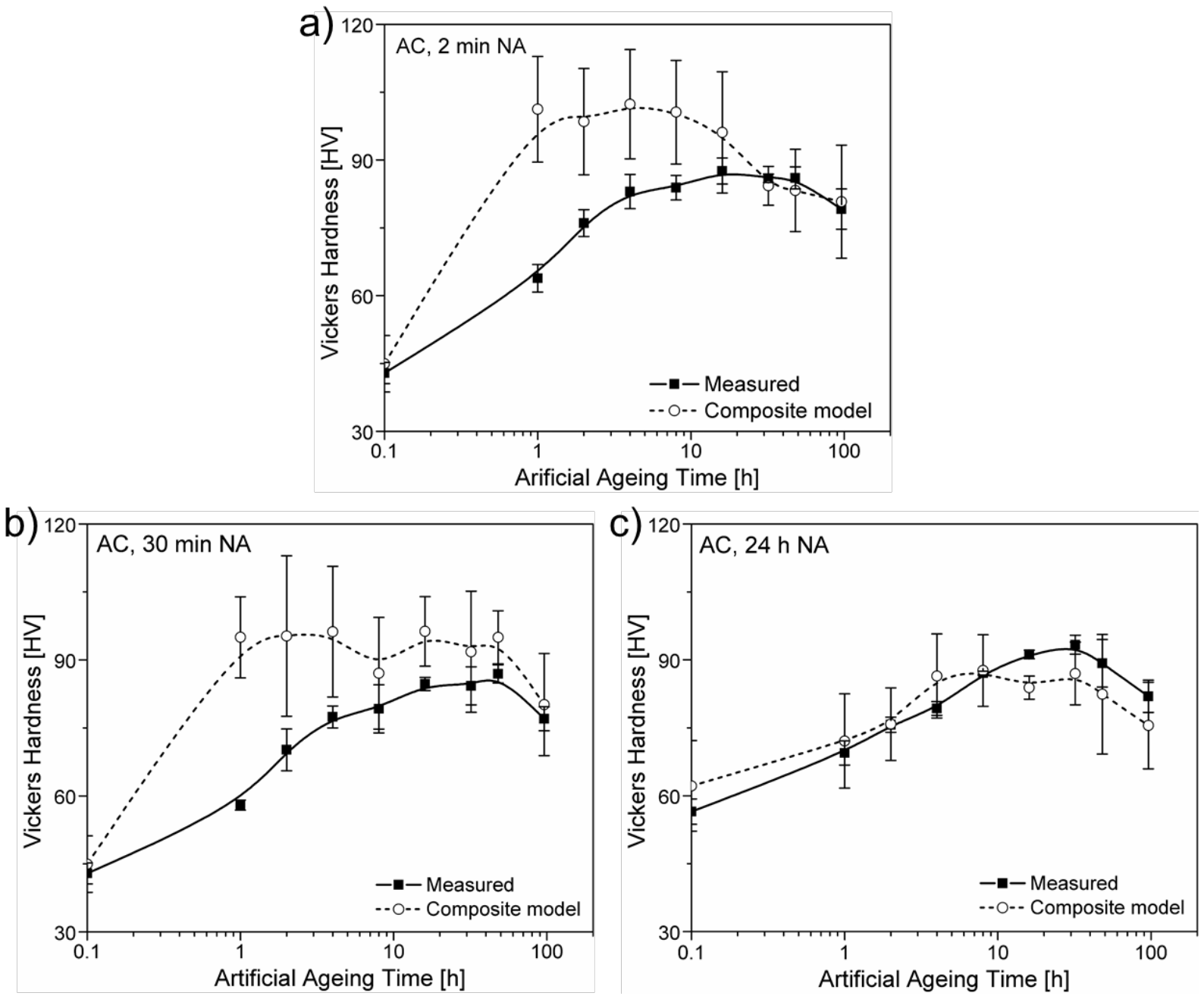

Figure 12 Comparison between the measured hardness data and those calculated according to the composite model for the AC samples after (a) $2 \mathrm{~min}$, (b) $30 \mathrm{~min}$ and (c) $24 \mathrm{~h}$ natural aging.

For the $24 \mathrm{~h}$ natural aging, the measured hardness is nearly identical to the calculated using the composite model, indicating that the quench sensitivity after prolonged natural aging can be explained fully by solute loss, i.e. dispersoid density. For short natural aging ( 2 min and $30 \mathrm{~min}$ ), the hardness measured is significantly lower than that would be expected if the effect of solute loss is considered. This indicates that vacancies must have a significant effect on the quench sensitivity.

Some models assume that solute is lost evenly and the reduced amount of solute leads to a reduction in driving force for precipitation $3,10,23,73$. However, it appears from this work that solute loss is not uniform but concentrated on distinct PFZs around dispersoids and nonhardening precipitates (Figure 7a) ${ }^{17,26}$. Thus, using the composite model is an alternative approach to modelling solute loss and is more mechanistically descriptive. 


\section{B. Effects of cooling rate and natural aging on quench sensitivity}

It has been demonstrated in the previous sections that both slow cooling after solution treatment and natural aging have a negative effect on the subsequent artificial aging response and consequently quench sensitivity (Figure 12). Slow cooling leads to solute loss through the formation of PFZs and a low concentration of quenched-in vacancies. Natural aging leads to annihilation of non-equilibrium vacancies which affects the precipitation process particularly clustering reactions.

A strong age hardening response can be expected when an alloy contains a homogeneously distributed, highly supersaturated solid solution as well as a high concentration of mobile nonequilibrium vacancies (Figure 11). In this study the WQ sample after 2 min natural aging is closest to this situation and therefore reaches highest peak hardness upon artificial aging (Figure 2a). The excellent hardening response in this condition is also associated with the preferential formation of the efficient strengthening $\beta$ "'-precipitates over the less efficient strengthening $\beta$ 'precipitates, as evidenced by the DSC analysis (Figure 4, Table $2 \&$ Table 3) and the TEM observations (Figure 9a).

A consequence of the excellent hardness achieved in the WQ sample naturally aged for $2 \mathrm{~min}$ is that this condition is also where the quench sensitivity (difference in hardness between the WQ and AC samples) is greatest ( $\sim 60 \mathrm{Hv}$ at 1 hour artificial aging) and where the greatest density of quenched in vacancies are available (Figure 11). In contrast, the 2 min naturally aged AC sample has a slow and less pronounced aging response because there are few quenched-in vacancies and the formation of the less effective hardening phase $\beta$ ' (Figure $4 \&$ Table 2).

It is noted that prolonged natural aging does not lead to a reduced hardness after artificial aging in the AC sample. Although the increment in hardness during artificial aging is less in the case of $24 \mathrm{~h}$ natural aging compared to $2 \mathrm{~min}$ and $30 \mathrm{~min}$ natural aging, the peak hardness is higher in the $24 \mathrm{~h}$ naturally aged sample. This is probably because the concentration of mobile, nonequilibrium vacancies is low after the slow cooling. Thus, the artificial aging has slow kinetics and is less affected by the natural aging. The simulations of the dependence of vacancy concentration on cooling rate predicts that the vacancy concentration after air cooling $(\sim 50-100$ $\mathrm{K} / \mathrm{min}$ ) is below that of the equilibrium concentration at the artificial aging temperatures, so the precipitation kinetics depends on thermal activation ${ }^{27,33,40}$. The PALS measurements of the 
AC sample do not show a peak within the first hour of natural aging, but rather a steady increase that leads to a peak after about 300 min natural aging, at which time the WQ and OQ samples have their second peak. The higher hardness of the $24 \mathrm{~h}$ naturally aged sample probably results from the enhanced clustering, which promotes the precipitation of more potent strengthening phases ${ }^{74}$.

The WQ and OQ samples, on the other hand, show a distinct negative effect of natural aging on subsequent artificial aging where the peak hardness for the $24 \mathrm{~h}$ natural aging is lower than that for the 2 min natural aging (Figure $2 \&$ Table 1). Cluster formation and vacancy annihilation lead to an increase in the activation energy for $\beta$ "-precipitation (Table 3 ) and consequently more $\beta$ ' precipitates are formed in the peak aged condition (Figure 10). This in turn results in a reduced peak hardness and a prolonged time to reach peak hardness during artificial aging (Figure 2c). This negative effect has been widely described in the literature for fast cooled samples $33,71,75,76$, and is in contrast to the positive natural aging effect often observed in alloys with combined $\mathrm{Mg}$ and Si contents below $1 \mathrm{wt} \%{ }^{22,63}$. Natural aging has been found to affect the precipitation sequence in 6000 series alloys previously and the explanations fit with the understanding presented in these studies ${ }^{63,77}$.

Hence, the effects of cooling rate and natural aging on quench sensitivity in Al-Mg-Si alloys cannot be fully explained by solute loss and annihilation of quenched-in vacancies. It appears that the precipitation sequence is also modifed and this provides an additional contribution to quench sensitivity.

\section{Conclusions}

The quench sensitivity in the Al-Mg-Si alloy with a high content of dispersoids has been found to be affected by the following three factors: (i) solute loss due to the formation of nonhardening $\beta$ ' precipitates on the dispersoids and formation of precipitate free zones around the dispersoids upon aging; (ii) slower precipitation kinetics due to reduction in the number of quenched-in vacancies due to slow cooling after solution treatment and natural aging; and (iii) the increased propensity for formation of the major strengthening phase $\beta$ " upon artificial aging with fast cooling and short natural aging. 
While the low quench sensitivity of the investigated alloy after the long natural aging $(24 \mathrm{~h})$ can be attributed almost entirely to the solute loss on the dispersoids, all three factors mentioned above are believed to be operating in the conditions where greater quench sensitivity is observed, i.e. after short natural aging $(2 \mathrm{~min}$ and $30 \mathrm{~min})$. The fast-quenched sample experiences the so called negative effect of natural aging, due to decreased aging kinetics and a reduced propensity of formation of the hardening $\beta$ " phase due to the preferential formation of the less efficient $\beta$ ' phase. The slight increment in hardness $(\sim 5 \mathrm{Hv})$ in the slow-cooled sample after prolonged natural aging $(24 \mathrm{~h})$ is related to an increased density of the $\beta$ ' phase.

\section{Acknowledgments}

The CAST Co-operative Research Centre was established under, and was supported in part by the Australian Government's Co-operative Research Centre program. The Monash Centre for Electron Microscopy is acknowledged for access to its facilities. Mr. Andy Yob of CSIRO is thanked for making the samples used in this work. ME also acknowledges the support of the ARC Training Centre for Lightweight Automotive Structures (project number IC160100032).

\section{References}

1. M.J. Starink, B. Milkereit, Y. Zhang, and P.A. Rometsch: Mater. Design, 2015. vol. 88, pp. 958971.

2. $\quad$ H. Zoller and A. Ried: Zeitschrift Metallkunde, 1971. vol. 62(5), pp. 5.

3. B. Milkereit and M.J. Starink: Mater. Design, 2015. vol. 76, pp. 117-129.

4. H. Westengen, L. Auran, and O. Reiso: Aluminium Dusseldorf, 1980. vol. 57(12), pp. 768-775.

5. L. Lodgaard and N. Ryum: Mater. Sci. Eng. A, 2000. vol. 283(1), pp. 144-152.

6. H. Hirasawa: Scripta Metallurgica, 1975. vol. 9(9), pp. 955-958.

7. J.A. Österreicher, M. Kumar, A. Schiffl, S. Schwarz, and G.R. Bourret: Mater. Sci. Eng. A, 2017. vol. 687, pp. 175-180.

8. H. Zhan and B. Hu: Mater. Char., 2018. vol. 142, pp. 602-612.

9. K. Buchanan, J. Ribis, J. Garnier, and K. Colas: Philosophical Magazine Letters, 2016. vol. 96(4), pp. 121-131.

10. D.H. Bratland, O. Grong, H. Shercliff, O.R. Myhr, and S. Tjotta: Acta Mater., 1997. vol. 45(1), pp. 1-22.

11. K. Strobel, M.A. Easton, L. Sweet, M.J. Couper, and J.-F. Nie: Mater. Trans., 2011. vol. 52(5), pp. 914-919.

12. L. Lodgaard and N. Ryum: Aluminum Transactions, 2000. vol. 2(2), pp. 267-275.

13. L. Lodgaard and N. Ryum: Mater. Sci. Tech., 2000. vol. 16(6), pp. 599-604.

14. L. Lodgaard and N. Ryum: Mater. Sci. Forum, 2000. vol. 331-337, pp. 945-950.

15. C.L. Liu, Q. Du, N. Parson, and W.J. Poole: Scripta Mater., 2018. vol. 152, pp. 59-63.

16. J. Yoo: J. Mater. Sci., 1999. vol. 34(11), pp. 2679. 
17. H. Bomas: Die Abschreckempfindlichkeit von manganhaltigen AIMgSi-Legierungen.

Fortschritt-Berichte der VDI-Zeitschriften, Reihe 5: Grund- und Werkstoffe. Vol. 47 pt 5. 1980, Düsseldorf: VDI-Verlag,,

18. I. Musulin and O.C. Celliers: Light Metals 1990, 1990, Publ by Minerals, Metals \& Materials Soc (TMS), pp. 951-954.

19. O. Lohne and A.L. Dons: Scand. J. Metall., 1983. vol. 12(1), pp. 34-36.

20. M.S. Remøe, K. Marthinsen, I. Westermann, K. Pederson, J. Røyset, and C. Marioara: Mater. Sci. Eng. A, 2017. vol. 693, pp. 60-72.

21. C. Flament, J. Ribis, J. Garnier, T. Vandenberghe, J. Henry, and A. Deschamps: Philos. Mag., 2015. vol. 95(8), pp. 906-917.

22. K. Strobel, M.D.H. Lay, M.A. Easton, L. Sweet, S. Zhu, N. Parson, and A.J. Hill: Materials Characterization, 2016. vol. 111, pp. 43-52.

23. J.W. Evancho and J.T. Staley: Metall. Trans., 1974. vol. 5(1), pp. 43-47.

24. D.W. Pashley, M.H. Jacobs, and J.T. Vietz: Philos. Mag., 1967. vol. 16, pp. 51-76.

25. A. Falahati, P. Lang, and E. Kozeschnik: Mater. Sci. Forum, 2012. vol. 706-709, pp. 317-322.

26. A. Deschamps, G. Texier, S. Ringeval, and L. Delfaut-Durut: Mater. Sci. Eng. A, 2009. vol. 501(1-2), pp. 133-139.

27. P. Lang, A. Falahati, M.R. Ahmadi, P. Warczok, E. Povoden-Karadeniz, E. Kozeschnik, and R. Radis: Phase Stability, Diffusion, Kinetics and their Applications, 2011, pp. 284-291.

28. M. Werinos, H. Antrekowitsch, T. Ebner, R. Prillhofer, P. Uggowitzer, and S. Pogatscher: Mater. Design, 2016. vol. 107, pp. 257-268.

29. M. Werinos, H. Antrekowitsch, E. Kozeschnik, T. Ebner, F. Moszner, J.F. Löffler, P. Uggowitzer, and S. Pogatscher: Scripta Mater., 2016. vol. 112, pp. 148-151.

30. S. Pogatscher, H. Antrekowitsch, M. Werinos, F. Moszner, S. Gerstl, M.F. Francis, W.A. Curtin, J.F. Löffler, and P. Uggowitzer: Phys. Rev. Letters, 2014. vol. 112, pp. 225701.

31. F.D. Fischer, J. Svoboda, F. Appel, and E. Kozeschnik: Acta Mater., 2011. vol. 59(9), pp. 34633472.

32. B. Klobes, T.E.M. Staab, M. Haaks, K. Maierand, and I. Wieler: Physica Status Solidi - Rapid Research Letters, 2008. vol. 2(5), pp. 224-226.

33. S. Pogatscher, H. Antrekowitsch, H. Leitner, T. Ebner, and P.J. Uggowitzer: Acta Mater., 2011. vol. 59(9), pp. 3352-3363.

34. H.S. Zurob and H. Seyedrezai: Scripta Mater., 2009. vol. 61(2), pp. 141-144.

35. R.C. Picu and X. Zhijie: Scripta Mater., 2007. vol. 57(1), pp. 45-48.

36. D.A. Porter, K.E. Easterling, and M.Y. Sherif: Phase transformations in matals and alloys. 3rd ed. 2009: CRC Press,

37. C. Wolverton: Acta Mater., 2007. vol. 55(17), pp. 5867-5872.

38. H. Seyedrezai, D. Grebennikov, P. Mascher, and H.S. Zurob: Mater. Sci. Eng. A, 2009. vol. 525(1-2), pp. 186-191.

39. S. Esmaeili, D. Vaumousse, M.W. Zandbergen, W.J. Poole, A. Cerezo, and D.J. Lloyd: Philos. Mag., 2007. vol. 87(25), pp. 3797-3816.

40. A. Falahati, M.R. Ahmadi, P. Warczok, P. Lang, E. Povoden-Karadeniz, and E. Kozeschnik: Phase Stability, Diffusion, Kinetics and their Applications, 2011, pp. 292-299.

41. S. Pogatscher, E. Kozeschnik, H. Antrekowitsch, M. Werinos, S. Gerstl, J.F. Löffler, and P. Uggowitzer: Scripta Mater., 2014. vol. 89, pp. 53-56.

42. P. Dumitraschkewitz, S. Gerstl, L. Stephenson, P. Uggowitzer, and S. Pogatscher: Adv. Engng. Mater., 2018. vol., pp. 1800255.

43. J. Banhart, M. Liu, Y. Yong, Z. Liang, C.S.T. Chang, M. Elsayed, and M.D.H. Lay: Physica B: Condensed Matter, 2012. vol. 407(14), pp. 2689-2696.

44. M.D.H. Lay, H.S. Zurob, C.R. Hutchinson, T.J. Bastow, and A.J. Hill: Metall. Mater. Trans. A, 2012. vol., pp. 1-7. 
45. J.F. Nie, B.C. Muddle, H.I. Aaronson, S.P. Ringer, and J.P. Hirth: Metall. Mater. Trans. A, 2002. vol. 33A(6), pp. 1649-1658.

46. H.W. Zandbergen, S.J. Andersen, and J. Jansen: Science, 1997. vol. 277(5330), pp. 1221-1225.

47. S.J. Andersen, H.W. Zandbergen, J. Jansen, C. Traeholt, U. Tundal, and O. Reiso: Acta Mater., 1998. vol. 46(9), pp. 3283-3298.

48. K. Matsuda, S. Ikeno, and S. Tada: J. Jpn. Inst. Met., 1993. vol. 57(10), pp. 1107-1113.

49. M.H. Jacobs: Philos. Mag., 1972. vol. 26(1), pp. 1-13.

50. R. Vissers, M.A. van Huis, J. Jansen, H.W. Zandbergen, C.D. Marioara, and S.J. Andersen: Acta Mater., 2007. vol. 55(11), pp. 3815-3823.

51. G.A. Edwards, K. Stiller, G.L. Dunlop, and M.J. Couper: Acta Mater., 1998. vol. 46, pp. 38933904.

52. T. Saito, E.A. Mørtsell, S. Wenner, C.D. Marioara, S.J. Andersen, J. Friis, K. Matsuda, and R. Holmestad: Adv. Engng. Mater., 2018. vol. 20(7), pp. 1800125.

53. K. Matsuda, V. Sakaguchi, V. Miyata, V. Uetani, T. Sato, A. Kamio, and S. Ikeno: J. Mater. Sci., 2000. vol. 35(1), pp. 179-189.

54. S. Wenner, L. Jones, C.D. Marioara, and R. Holmestad: Micron, 2017. vol. 96, pp. 103-111.

55. M.J. Starink: International Materials Reviews, 2004. vol. 49(3-4), pp. 191-226.

56. J.M. Zuo and M. J.C., in Microsc Microanal 10 (Suppl 2). 2004.

57. R. Ferragut, A. Somoza, and A. Dupasquier: Journal of Physics: Condensed Matter, 1998. vol. 10(17), pp. 3903-3918.

58. G. Dlubek: Material Science Forum, 1987. vol. 13-14, pp. 11-32.

59. J. Banhart, M.D.H. Lay, C.S.T. Chang, and A.J. Hill: Phys. Rev. B: Condens. Matter, 2011. vol. 83(1), pp. 13.

60. A. Somoza, A. Dupasquier, I.J. Polmear, P. Folegati, and R. Ferragut: Physical Review B (Condensed Matter), 2000. vol. 61(21), pp. 14454-14463.

61. J. Royset, T. Stene, J.A. Saeter, and O. Reiso: Mater. Sci. Forum, 2006. vol. 519-521, pp. 239244.

62. D.W. Pashley, J.W. Rhodes, and A. Sendorek: J. Inst. Metals, 1966. vol. 94, pp. 41-49.

63. A. Poznak, V. Thole, and P. Sanders: Metals, 2018. vol. 8, pp. 309.

64. B. Milkereit, in Fakultät für Maschinenbau und Schiffstechnik. 2010, Universität Rostock: Rostock. pp. 178.

65. M.J. Starink: Thermochim Acta, 2003. vol. 404, pp. 163-176.

66. M.J. Starink: J. Alloys Compd., 2007. vol. 433(1-2), pp. 4-6.

67. A. Dupasquier, G. Kogel, and A. Somoza: Acta Mater., 2004. vol. 52(16), pp. 4707-4726.

68. T.E.M. Staab, B. Klobes, I. Kohlbach, B. Korff, M. Haaks, E. Dudzik, and K. Maier: J. Phys: Conf. Series, 2011. vol. 265, pp. 15.

69. J.M. Campillo Robles, E. Ogando, and F. Plazaola: International Workshop on Positron Studies of Defects, 2011, IOP Publishing Ltd., pp. 1-10.

70. J. Banhart, C.S.T. Chang, Z. Liang, N. Wanderka, M.D.H. Lay, and A.J. Hill: Adv. Engng. Mater., 2010. vol. 12(7), pp. 559-571.

71. C.S.T. Chang and J. Banhart: Metall. Mater. Trans. A, 2010. vol. 42(7), pp. 1960-1964.

72. B. Milkereit, N. Wanderka, C. Schick, and O. Kessler: Mater. Sci. Eng. A, 2012. vol. 550, pp. 8796.

73. J.T. Staley: Mater. Sci. Tech., 1987. vol. 3(11), pp. 923.

74. C.S.T. Chang, I. Wieler, N. Wanderka, and J. Banhart: Ultramicroscopy, 2009. vol. 109(5), pp. 585-592.

75. A. Serizawa, S. Hirosawa, and T. Sato: Metall. Mater. Trans. A, 2008. vol. 39(2), pp. 243-251.

76. M. Murayama and K. Hono: Acta Mater., 1999. vol. 47(5), pp. 1537-1548.

77. Y.X. Lai, B.C. Jiang, C.H. Liu, Z.K. Chen, C.L. Wu, and J.H. Chen: J. Alloys Compd., 2017. vol. 701, pp. 94-98. 
617

618

619 
620

621

622

623

624

625

626

627

628

629

630

631

632

633

634

635

636

637

638

639

640

641

642

643

644

645

646

647

648

649

650

651

652

\section{Figure Captions}

Figure 1 Age hardening response of the WQ, OQ and AC samples during natural aging.

Figure 2 Artificial age hardening response at $448 \mathrm{~K}\left(175^{\circ} \mathrm{C}\right)$ for the WQ, OQ and AC samples after (a) 2 min, (b) 30 min and (c) $24 \mathrm{~h}$ natural aging.

Figure 3 (a) DSC curves during cooling from $823 \mathrm{~K}\left(550^{\circ} \mathrm{C}\right)$ at different cooling rates showing the precipitation of $\beta-\mathrm{Mg} 2 \mathrm{Si}$ (high temperature peak) and $\beta$ ' (low temperature peak) in the alloy. It should be noted that the baseline for the different cooling rates is offset for clarity. (b) Enthalpies of precipitation during cooling plotted against cooling rate. Also shown in (b) are hardness data measured on the samples cooled at different rates.

Figure 4 DSC curves at a heating rate of $20 \mathrm{~K} / \mathrm{min}$ for the WQ and AC samples naturally aged for (a) $30 \mathrm{~min}$ and (b) $24 \mathrm{~h}$. The letters A to E indicate exo- and endothermic peaks.

Figure 5 Enthalpies for formation of cluster, $\beta$ " and $\beta$ ' during heating at $20 \mathrm{~K} / \mathrm{min}$ for the WQ and AC samples after natural aging for $30 \mathrm{~min}$ and $24 \mathrm{~h}$ showing the relative amounts of phases that are formed.

Figure 6 SEM backscattered electron image showing $\alpha-\mathrm{Al}(\mathrm{Fe}, \mathrm{Mn}) \mathrm{Si}$ intermetallics (arrowed) and dispersoids in the alloy after the homogenization treatment.

Figure 7 (a) TEM micrograph showing the non-hardening $\beta$ ' precipitates nucleated on the coarse dispersoids in the AC sample naturally aged for $24 \mathrm{~h}$ and then artificially aged for $8 \mathrm{~h}$ at $448 \mathrm{~K}\left(175^{\circ} \mathrm{C}\right)$, (b) typical EDX spectrum and (c) plot of the EDX measured Mg content versus $\mathrm{Si}$ content of the $\beta^{\prime}$ precipitates. The $\mathrm{Mg}$ :Si-ratio of ten $\beta^{\prime}$ precipitates found on dispersoids throughout the alloy which is observed to be close to that of $\mathrm{Mg}_{2} \mathrm{Si}$ phase. The arrows in (a) indicate the $\beta^{\prime}$ precipitates in two different orientations.

Figure 8 (a) Selected area diffraction pattern of a non-hardening precipitate and matrix from $[0001] \beta$ '//[001] Al and (b) schematic illustration of a $\beta$ '-precipitate and Al-matrix. Open and closed circles indicated diffraction spots of the precipitate and matrix, respectively.

Figure 9 TEM micrographs along <001 $>\mathrm{Al}$ showing precipitates in the (a) WQ and (b) AC samples after $30 \mathrm{~min}$ natural aging and further $1 \mathrm{~h}$ artificial aging at $448 \mathrm{~K}\left(175^{\circ} \mathrm{C}\right)$. Both images are the same scale.

Figure 10 TEM micrographs along <001>Al showing precipitates in the (a) WQ and (b) AC samples after $24 \mathrm{~h}$ natural aging and further $8 \mathrm{~h}$ artificial aging at $448 \mathrm{~K}\left(175^{\circ} \mathrm{C}\right)$. Both images are the same scale.

Figure 11 Evolution of the average positron lifetime, $\tau A V$, in the WQ, OQ and AC samples during natural aging. 
653 Figure 12 Comparison between the measured hardness data and those calculated according to 654 the composite model for the AC samples after (a) $2 \mathrm{~min}$, (b) $30 \mathrm{~min}$ and (c) $24 \mathrm{~h}$ natural 655 aging.

656 
657

658

659

\begin{tabular}{ccccccc}
\hline \multirow{2}{*}{$\begin{array}{c}\text { Natural Aging } \\
\text { Time }\end{array}$} & \multicolumn{3}{c}{$\begin{array}{c}\text { Hardness [Hv] } \\
\text { (Natural Aging) }\end{array}$} & \multicolumn{3}{c}{$\begin{array}{c}\text { Peak Hardness [Hv] } \\
\text { (Artificial Aging) }\end{array}$} \\
\cline { 2 - 7 } & WQ & OQ & AC & WQ & OQ & AC \\
\hline 2 min & $45 \pm 2$ & $41 \pm 1$ & $43 \pm 2$ & $117 \pm 5(1 \mathrm{~h})$ & $112 \pm 3(4 \mathrm{~h})$ & $88 \pm 3(16 \mathrm{~h})$ \\
$30 \mathrm{~min}$ & $50 \pm 2$ & $48 \pm 3$ & $47 \pm 2$ & $110 \pm 6(4 \mathrm{~h})$ & $103 \pm 3(4 \mathrm{~h})$ & $87 \pm 2(48 \mathrm{~h})$ \\
$24 \mathrm{~h}$ & $67 \pm 4$ & $63 \pm 3$ & $57 \pm 3$ & $100 \pm 6(8 \mathrm{~h})$ & $91 \pm 3(8 \mathrm{~h})$ & $93 \pm 2(32 \mathrm{~h})$ \\
\hline
\end{tabular}

Table 1. Summary of the hardness at different natural aging times and the peak hardness and the time to peak hardness (in bracket) upon artificial aging at $175^{\circ} \mathrm{C}$.

660

661

662 
663

664

665

\begin{tabular}{ccccccc}
\hline & \multicolumn{2}{c}{ Clustering $(\mathrm{A})$} & \multicolumn{2}{c}{$\beta$ ' Formation $(\mathrm{C})$} & \multicolumn{2}{c}{$\beta$ ' Formation (D) } \\
\cline { 2 - 7 } Sample & $\begin{array}{c}\text { Peak } \\
\text { Temperature } \\
{[\mathrm{K}]}\end{array}$ & $\begin{array}{c}\text { Enthalpy } \\
{[\mathrm{J} / \mathrm{g}]}\end{array}$ & $\begin{array}{c}\text { Peak } \\
\text { Temperature } \\
{[\mathrm{K}]}\end{array}$ & $\begin{array}{c}\text { Enthalpy } \\
{[\mathrm{J} / \mathrm{g}]}\end{array}$ & $\begin{array}{c}\text { Peak } \\
\text { Temperature } \\
{[\mathrm{K}]}\end{array}$ & $\begin{array}{c}\text { Enthalpy } \\
{[\mathrm{J} / \mathrm{g}]}\end{array}$ \\
\hline $\mathrm{WQ}+$ 30 min NA & $356 \pm 2$ & $1.6 \pm 0.4$ & $557 \pm 2$ & $12 \pm 0.5$ & $595 \pm 1$ & $6.4 \pm 0.2$ \\
WQ + 24 h NA & $369 \pm 2$ & $0.3 \pm 0.1$ & $562 \pm 2$ & $11 \pm 0.6$ & $603 \pm 1$ & $3.7 \pm 0.6$ \\
AC + 30 min NA & - & - & $545 \pm 4$ & $3.5 \pm 0.2$ & $600 \pm 2$ & $7.2 \pm 0.4$ \\
AC 24 h + NA & - & - & $559 \pm 1$ & $2.8 \pm 0.3$ & $598 \pm 1$ & $6.3 \pm 0.3$
\end{tabular}

Table 2. The peak temperature and formation enthalpy for $\beta$ " and $\beta$ ' formation in the WQ and $\mathrm{AC}$ samples after $30 \mathrm{~min}$ and $24 \mathrm{~h}$ natural aging during heating at $20 \mathrm{~K} / \mathrm{min}$.

666 
668

669

670

\begin{tabular}{cccccc}
\hline Sample & $\begin{array}{c}\text { Cluster } \\
\text { Formation } \\
\left(\mathrm{kJ} \mathrm{mol}^{-1}\right)\end{array}$ & $\begin{array}{c}\text { Cluster } \\
\text { Dissolution } \\
\left(\mathrm{kJ} \mathrm{mol}^{-1}\right)\end{array}$ & $\begin{array}{c}\beta ”- \\
\text { Precipitation } \\
\left(\mathrm{kJ} \mathrm{mol}^{-1}\right)\end{array}$ & $\begin{array}{c}\beta ” \text { to } \beta \text { '- } \\
\text { Transformation } \\
\left(\mathrm{kJ} \mathrm{mol}^{-1}\right)\end{array}$ & $\begin{array}{c}\beta \text {-Formation } \\
\left(\mathrm{kJ} \mathrm{mol}^{-1}\right)\end{array}$ \\
\hline $\mathrm{WQ}+30$ min NA & 47 & 128 & 92 & 100 & 231 \\
$\mathrm{WQ}+24 \mathrm{~h}$ NA & 32 & 165 & 109 & 111 & 476 \\
$\mathrm{AC}+30$ min NA & - & - & 162 & 105 & 281 \\
$\mathrm{AC}+24 \mathrm{~h} \mathrm{NA}$ & - & - & 90 & 96 & 418 \\
\hline $\begin{array}{c}\mathrm{Al}-1.12 \\
\text { wt. } \% \mathrm{Mg} \text { Si-0.35 } \\
\text { wt. } \% \mathrm{Si} \text { 66 }\end{array}$ & - & - & 76.6 & 117.3 & 117.4 \\
\hline
\end{tabular}

Table 3. Activation energy of phase transformation occurring during heating for WQ and AC samples after $30 \mathrm{~min}$ and $24 \mathrm{~h}$ natural aging.

671 